\title{
Effect of Infill Walls on the Seismic Performance of an Old Building
}

\author{
Uğur Albayrak, Eşref Ünlüoğlu, and Mizam Doğan
}

\begin{abstract}
The effect of the existence of infill walls on the earthquake performance of a structure is one of the main research areas in terms of seismic safety. This study present a performance based approach to the entrenched procedures for seismic design of buildings contained in standards as Turkish Seismic Code. In this manner, an existing 55 years old industrial R.C. building in Eskisehir, Turkey was modelled and performance-based seismic design deal with the verification of seismic performance uttered in terms of limit states defined in Turkish Seismic Code. Three dimensional finite elements modelling of the building was created based on the measurements and observations on site. SAP2000 was utilized to make earthquake analysis of the 3-D numerical model of the building. According to the results from the performance evaluation of entire building; the contribution of the infill walls to the strength and stiffness of entire structure can be easily demonstrated. These results from performance based design procedure indicate that infill walls in this building are the main reason why this insufficient building in terms of earthquake resistance has been survived for many years under effective earthquakes.
\end{abstract}

Index Terms - Infill walls, old building, performance based design, Turkish seismic code.

\section{INTRODUCTION}

Turkey is one of the most earthquakes occurred countries and suffered from some of the worst earthquakes in the world. Especially North-western part of Turkey which is the county's most densely populated region and industrial heartland has been struck by major earthquakes in history. The most powerful earthquake to hit Turkey is Izmit Earthquake, on 17 August 1999 measured 7.4 on the Richter scale and continued 45 seconds, killing around 17,000 people and cause 500,000 people homeless [1].

Most codes require that all new buildings must be able to survive after a major earthquake [2]. The building can crack, tilt and even be declared unfit for future use but it must not totally collapse [3]. In Turkish Seismic Code (TSC), the crucial factor to fix life losses at a certain low level is about the building code itself and its application in casual life [4]. The main aim of the code is to define the minimum requirements for seismic design and construction of reinforced or steel etc... buildings and structures which is

subjected to earthquake ground motion. The code requirements must be applicable to newly constructed

Manuscript received February 13, 2017; revised May 1, 2017.

The authors are with Eskisehir Osmangazi University, Dept. of Civil Engineering, Eskisehir, Turkey (e-mail: albayrak@ogu.edu.tr, esrefu@ogu.edu.tr, mizan@ogu.edu.tr). buildings as well as to existing old buildings [4]. The general principle of the code is to limit the damage in structural elements and to prevent the total collapse of buildings in major earthquakes in order to avoid the loss of life. On the other hand, effect of the infill walls on the earthquake performance of a structure is one of the main research areas in terms of seismic safety [5]. Behavior of a R.C. building with infill walls under seismic loads should be modeled to consider the effect of the infill walls on the seismic performance of the structure [6].

\section{METHOD}

Investigation and evaluation of earthquake performance of the existing building are carried out according to the essentials for TSC [4]. The building which is investigated in this paper can be assessed according to the rules that defined in relevant section of the code. After an earthquake causing damage in the building, and then to determine the earthquake performance of the strengthened building, essentials given in the code will be used.

First of all, all necessary data have to be collected from the building by measurements to be achieved on the building such the geometry and details of the R.C. elements and materials to be used in determining the capacities of the elements of the existing building [7]. The collected data from the investigation of the buildings determine the information level of the buildings which can be classified as limited, medium and comprehensive where the limited level is defined as there is not any projects of the structural system about the building. Characteristics of materials and existing materials strengths used in the building were determined by collecting at least two samples of borehole concrete from columns and beams. Reinforcement details can be determined according to the visual examination and performing test on the rebar samples. According to the test results, characteristic yield strength of the rebar can be taken as the existing steel strength which is taken into calculations of the element capacities [8]. Information Level Coefficients to be used in the calculation of element capacities can be obtained from the investigated building so it is taken as 0.75 for limited information level.

Performance-based seismic design deal with the verification of seismic performance uttered in terms of limit states defined below [9]. Three limit conditions of damage were defined for ductile elements as Minimum Damage Limit $(\mathrm{MN})$, Safety Limit (GV) and Collapsing Limit (GC) in Turkish Seismic Code while this classification is not suitable for brittle case. The structural elements that the damages with critical sections do not reach MN are within the Minimum Damage Region, those in-between $\mathrm{MN}$ and $\mathrm{GV}$ are within 
Marked Damage Region, those in-between GV and GÇ are in Advanced Damage Region, and those going beyond GÇ are within Collapsing Region given in Fig. 1 [4].

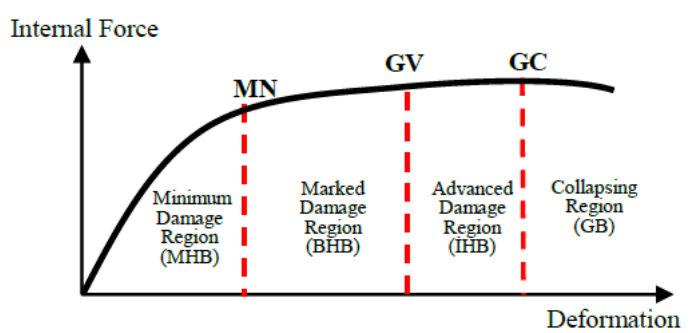

Fig. 1. Sectional damaged areas according to [4].

In order to be able to decide which damage zone the sections are in, it is first necessary to determine internal forces and/or deformations using linear elastic calculation methods or linear non-elastic calculation methods [10]. After this process, the sections are compared with the numerical values with damage limits to define proper damage zone considering the most damaged section.

\section{A. General Principles Related to Earthquake Damage Determination}

Elastic acceleration spectrum (non-reduced) will be used for the definition of the earthquake. Building Importance Factor $(I=1.0)$ varied in terms of the purpose of occupancy or building type will not be applied in the seismic calculation. Earthquake forces act on the building in both directions and on both sides separately. The ground parameters such as soil group and local site class were to be considered that will be used in seismic calculations, were have been determined according to Turkish Seismic Code [4]. In the building calculation process, the slabs were assumed as rigid diaphragms on the horizontal axis ( $\mathrm{z}$ ) and any additional eccentricity had not been applied [11]. Information level coefficient of the building was used to identify some deficiencies or uncertainty on the load-bearing systems. All of the columns in the building were defined in the structural model with their free heights. Confinement zones at the beam-column connections can be considered as infinitely rigid end [12]. In reinforced concrete elements under bending effect, Active bending rigidities $(\mathrm{EI})_{\mathrm{e}}$ of the cracked sections should be used. In order to do this, the rigidity values given below should be replaced for active bending rigidities [4]:

$$
\begin{array}{lll}
\text { - Beams } \quad(\mathrm{EI})_{\mathrm{e}}=0.40(\mathrm{EI})_{\mathrm{o}} & \\
\text { - Columns and frames, } & (\mathrm{EI})_{\mathrm{e}}=0.40(\mathrm{EI})_{\mathrm{o}} \text { if } & N_{D} /\left(A_{c} f_{c m}\right) \leq 0.10 \\
(\mathrm{EI})_{\mathrm{e}}=0.80(\mathrm{EI})_{\mathrm{o}} \text { if } & N_{D} /\left(A_{c} f_{c m}\right) \geq 0.40
\end{array}
$$

For the case of insufficient coupling or splicing length in structural members, yield tensile of the reinforcement should be reduced in proportion as the shortening in length.

\section{CASE STUDY}

The earthquake performance of a 55 year old reinforced concrete structure was determined by using the Equivalent Seismic Load Method, which is one of the linear elastic calculation methods described before [13]. The examined building with 6-storey which is divided into administrative and production parts was built in 1962 as a flour factory and the production was stopped in 2003 (Fig. 2).
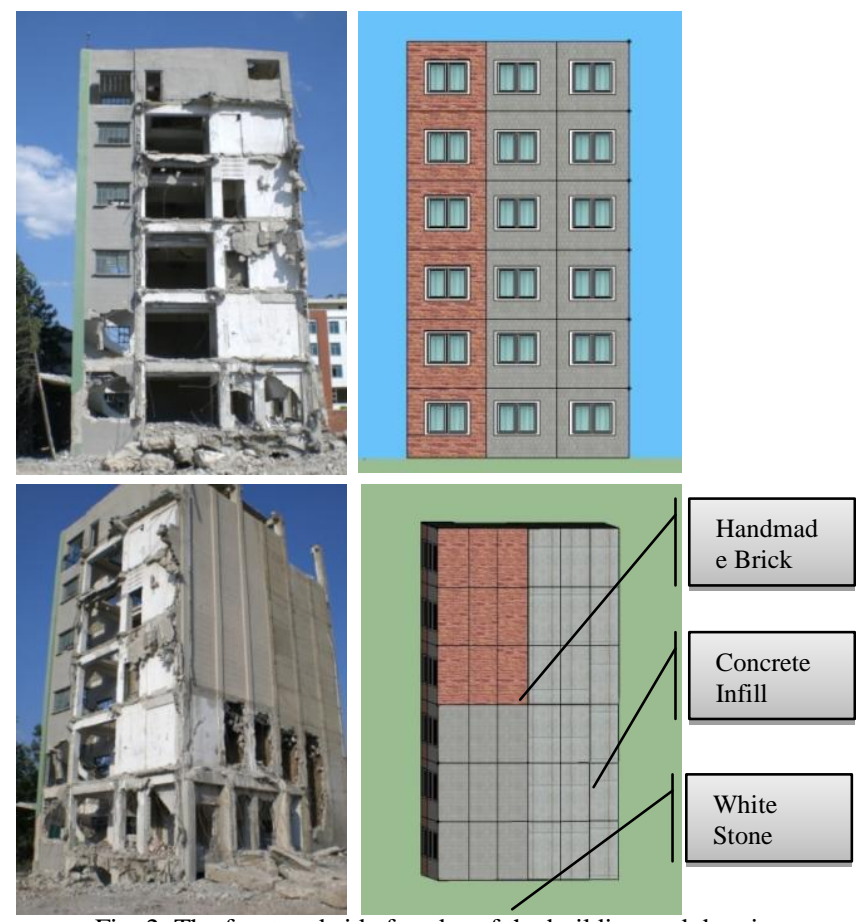

Fig. 2. The front and side facades of the building and drawings.

\section{A. Three Dimensional Finite Element Modelling of the Building}

A 6 story R.C. building presented below as a case study to define the effect of the infill walls on the seismic performance of an old building. Three dimensional finite element modelling of the building was created based on the measurements and observations on site. SAP2000 was utilized to make earthquake analysis of the structure [14]. 3-D numerical model of the building was consisting of beams, columns, slabs and walls are shown in Fig. 3. All beams and columns of the building were considered as frame elements whereas slabs were thin plates and walls were shell elements.

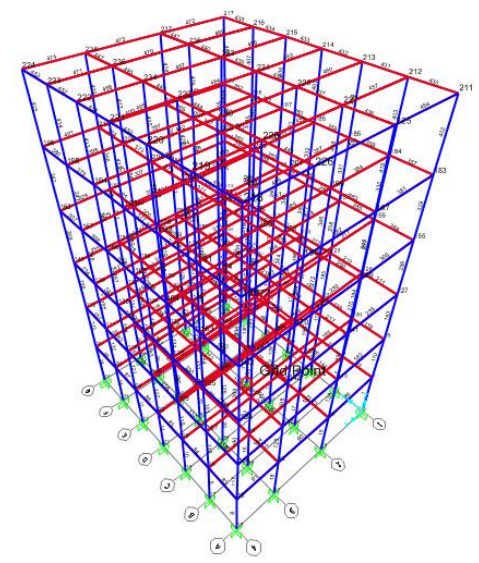

Fig. 3. 3-D finite element model of the load-bearing system.

Process to be used for the seismic analysis of building is equivalent seismic load method and modal analysis to determine earthquake performance of the building with and without infill walls. According to the first results from the 
observations on site, columns dimensions are not adequate whereas concrete quality was also poor. Adhesion between steel rebar and concrete is not sufficient to prevent pull-out failure. Information about the building is given in Table I.

TABLE I: ALL INFORMATION ABOUT THE BUILDING

\begin{tabular}{|c|c|c|c|}
\hline \multirow{4}{*}{$\stackrel{\infty}{\Xi}$} & \multirow{4}{*}{ 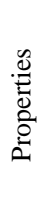 } & Story height & $3 \mathrm{~m}$ \\
\hline & & Earthquake zone & 2 \\
\hline & & Local site class & $\mathrm{Z4}$ \\
\hline & & Spectrum characteristic periods & $0.20 / 0.90$ \\
\hline \multirow{4}{*}{ 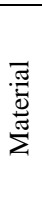 } & \multirow{4}{*}{ 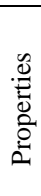 } & Concrete & $\mathrm{C} 10$ \\
\hline & & Reinforcement Steel & S220 / Plain \\
\hline & & Modulus of elasticity of concrete & $25300 \mathrm{Mpa}$ \\
\hline & & Modulus of elasticity of steel & $2 \times 10^{5} \mathrm{Mpa}$ \\
\hline \multirow{4}{*}{$\frac{\pi}{\sqrt{n}}$} & \multirow{4}{*}{ 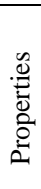 } & Reinforced concrete thickness & $15 \mathrm{~cm}$ \\
\hline & & Leveling concrete thickness & $5 \mathrm{~cm}$ \\
\hline & & Plaster (lime-cement mixture) & $2 \mathrm{~cm}$ \\
\hline & & Coating & $2 \mathrm{~cm}$ \\
\hline
\end{tabular}

Plan view at the first floor of the models is given in Fig. 4.

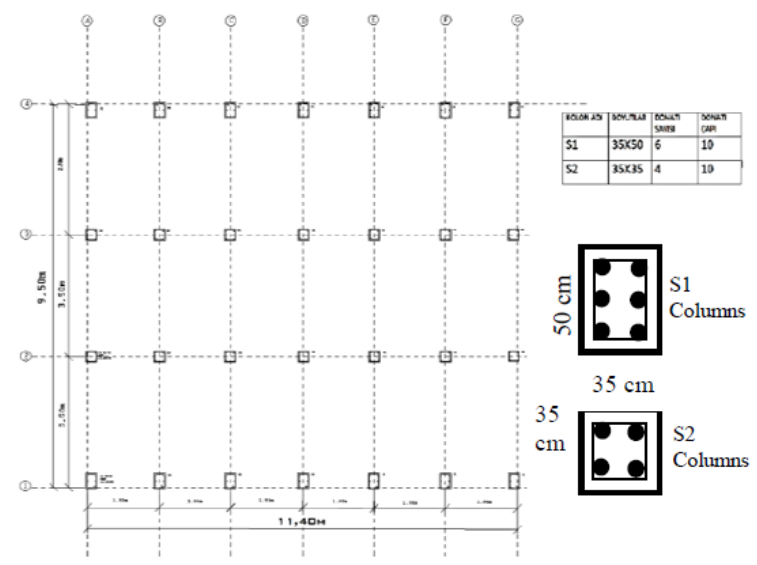

Fig. 4. Plan view of the building.

The structure were analyzed and according to axial load level of the columns Active bending rigidities $(\mathrm{EI})_{\mathrm{e}}$ of the cracked sections calculated by interpolation between 0.40 and 0.80 values using the Eq. 1 below and given in the Table II [4]:

$$
0.10 \leq N_{D} /\left(A_{c}^{*} f_{c m}\right) \leq 0.40
$$

Effect / capacity ratio of ductile beam, column and walls are calculated by dividing the section moment calculated under seismic load by taking $R_{a}=1$ to over moment capacity. On the calculation of effect / capacity direction of the earthquake can be taken into consideration [4].

According to TSC [4], over moment capacities which are the difference between bending moment capacity and moment effect calculated on the section under gravity loads of the all beams in the structure were calculated. All of the beams are the same dimensions and tensile and compressive reinforcement are the same thence moment capacity at point $i$ is equal but negative sign to point $\mathrm{j}$ and it can be calculated with Eq. 2 and 3 given in below [4]:

$$
\begin{gathered}
M_{r}=0.85 f_{c d} b_{w} k_{1} c\left[d-\left(k_{1} c\right) / 2\right]+A_{s}^{l} \sigma_{s}^{l}\left(d-d^{l}\right) \\
\mathrm{c}=\left(A_{s}-A_{s}{ }^{\prime}\right) f_{y d} /\left(0.85 f_{c d} b_{w} k_{1}\right)
\end{gathered}
$$

Over moment capacities $\left(M_{R}\right)$ and redundant moment capacities $\left(M_{D}\right)$ of the sections on the direction $\mathrm{X}$ and $\mathrm{Y}$ can be calculated and only $\mathrm{X}$ direction beams are given in Table III.

TABLE III: MOMENT CAPACITIES OF THE X DiRECTION BEAMS AT FIRST

\begin{tabular}{rrrrrrr} 
Beam & $\begin{array}{r}M_{R i} \\
(\mathrm{kNm})\end{array}$ & $\begin{array}{r}M_{R j} \\
(\mathrm{kNm})\end{array}$ & $\begin{array}{r}M_{D i} \\
(\mathrm{kNm})\end{array}$ & $\begin{array}{r}M_{D j} \\
(\mathrm{kNm})\end{array}$ & $\begin{array}{r}M_{A i} \\
(\mathrm{kNm})\end{array}$ & $\begin{array}{r}M_{A j} \\
(\mathrm{kNm})\end{array}$ \\
\hline B1 & 21.27 & -21.17 & -1.757 & 0.8894 & 22.927 & 20.2806 \\
B2 & 21.27 & -21.17 & -0.489 & -0.1692 & 21.659 & 21.3392 \\
B3 & 21.27 & -21.17 & -0.6414 & -0.5983 & 21.8114 & 21.7683 \\
B4 & 21.27 & -21.17 & -0.5983 & -0.6414 & 21.7683 & 21.8114 \\
B5 & 21.27 & -21.17 & -0.1692 & -0.489 & 21.3392 & 21.659 \\
B6 & 21.27 & -21.17 & 0.8894 & -1.757 & 20.2806 & 22.927 \\
B7 & 21.27 & -21.17 & -2.5479 & 2.0667 & 23.7179 & 19.1033 \\
B8 & 21.27 & -21.17 & 0.1195 & 0.2183 & 21.0505 & 20.9517 \\
B9 & 21.27 & -21.17 & -0.4469 & -0.462 & 21.6169 & 21.632 \\
B10 & 21.27 & -21.17 & -0.462 & -0.4469 & 21.632 & 21.6169 \\
B11 & 21.27 & -21.17 & 0.2183 & 0.1195 & 20.9517 & 21.0505 \\
B12 & 21.27 & -21.17 & 2.0667 & -2.5479 & 19.1033 & 23.7179 \\
B13 & 21.27 & -21.17 & -2.2032 & 1.6753 & 23.3732 & 19.4947 \\
B14 & 21.27 & -21.17 & 0.0048 & 0.0519 & 21.1652 & 21.1181 \\
B15 & 21.27 & -21.17 & -0.5042 & -0.5231 & 21.6742 & 21.6931 \\
B16 & 21.27 & -21.17 & -0.5231 & -0.5042 & 21.6931 & 21.6742 \\
B17 & 21.27 & -21.17 & 0.0519 & 0.0048 & 21.1181 & 21.1652 \\
B18 & 21.27 & -21.17 & 1.6753 & -2.2032 & 19.4947 & 23.3732 \\
B19 & 21.27 & -21.17 & -1.5474 & 0.6482 & 22.7174 & 20.5218 \\
B20 & 21.27 & -21.17 & -0.5835 & -0.2169 & 21.7535 & 21.3869 \\
B21 & 21.27 & -21.17 & -0.6602 & -0.6091 & 21.8302 & 21.7791 \\
B22 & 21.27 & -21.17 & -0.6091 & -0.6602 & 21.7791 & 21.8302 \\
B23 & 21.27 & -21.17 & -0.2169 & -0.5835 & 21.3869 & 21.7535 \\
B24 & 21.27 & -21.17 & 0.6482 & -1.5474 & 20.5218 & 22.7174 \\
\hline
\end{tabular}

Redundant moment capacity $M_{A}$ and corresponding axial force $\mathrm{N}_{\mathrm{A}}$ defined as follows [4]:

$$
\begin{aligned}
M_{A} & =M_{K}-M_{D} \\
N_{A} & =N_{K}-N_{D}
\end{aligned}
$$

And effect / capacity ratios (r) of columns and walls may be defined as follows [4]:

$$
r=M_{E} / M_{A}=N_{E} / N_{A} \leq r_{s}
$$

where $M_{D}$ or $N_{D}$ is known from gravity load design and $\mathrm{M}_{\mathrm{E}}$ or $\mathrm{N}_{\mathrm{E}}$ is known from seismic design.

Moment and axial force capacities of the column sections $\left(M_{K}, N_{K}\right)$ as the coordinates of $K$ intersection point in Fig. 5 is obtained from geometrically or using the equations [4].

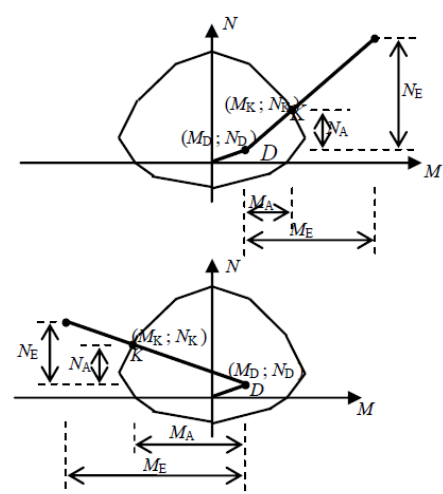

Fig. 5. Moment and axial force capacities of the column sections $\left(M_{K}, N_{K}\right)$ [4]. 
TABLE II: ACTIVE BENDING RIGIDITIES OF CRACKED SECTIONS AT FIRST FLOOR

\begin{tabular}{|c|c|c|c|c|}
\hline $\begin{array}{c}\text { Element } \\
\text { No }\end{array}$ & $\begin{array}{c}\mathrm{N}_{\mathrm{d}} \\
(\mathrm{kN})\end{array}$ & $\begin{array}{c}\mathrm{A}_{\mathrm{c}} \\
\left(\mathrm{mm}^{2}\right)\end{array}$ & $N_{D} /\left(A c^{*} f \mathrm{~cm}\right)$ & (EI)。 \\
\hline 1 & 281.705 & 175000 & 0.134145 & 0.57886 \\
\hline 2 & 335.995 & 175000 & 0.159998 & 0.61333 \\
\hline 3 & 359.123 & 175000 & 0.171011 & 0.628015 \\
\hline 4 & 364.24 & 175000 & 0.173448 & 0.631263 \\
\hline 5 & 359.123 & 175000 & 0.171011 & 0.628015 \\
\hline 6 & 335.995 & 175000 & 0.159998 & 0.61333 \\
\hline 7 & 281.705 & 175000 & 0.134145 & 0.57886 \\
\hline 8 & 250.214 & 122500 & 0.170214 & 0.626951 \\
\hline 9 & 298.092 & 122500 & 0.202784 & 0.670378 \\
\hline 10 & 319.003 & 122500 & 0.217009 & 0.689345 \\
\hline 11 & 323.799 & 122500 & 0.220271 & 0.693695 \\
\hline 12 & 319.003 & 122500 & 0.217009 & 0.689345 \\
\hline 13 & 298.092 & 122500 & 0.202784 & 0.670378 \\
\hline 14 & 250.214 & 122500 & 0.170214 & 0.626951 \\
\hline 15 & 319.227 & 122500 & 0.217161 & 0.689548 \\
\hline 16 & 278.886 & 122500 & 0.189718 & 0.652958 \\
\hline 17 & 388.583 & 122500 & 0.264342 & 0.752456 \\
\hline 18 & 338.96 & 122500 & 0.230585 & 0.707447 \\
\hline 19 & 418.031 & 122500 & 0.284375 & 0.779166 \\
\hline 20 & 363.906 & 122500 & 0.247555 & 0.730073 \\
\hline 21 & 424.216 & 122500 & 0.288582 & 0.784776 \\
\hline 22 & 369.086 & 175000 & 0.175755 & 0.63434 \\
\hline 23 & 418.031 & 175000 & 0.199062 & 0.665417 \\
\hline 24 & 363.906 & 175000 & 0.173289 & 0.631051 \\
\hline 25 & 388.583 & 175000 & 0.18504 & 0.646719 \\
\hline 26 & 338.96 & 175000 & 0.16141 & 0.615213 \\
\hline 27 & 319.227 & 175000 & 0.152013 & 0.602684 \\
\hline 28 & 278.886 & 175000 & 0.132803 & 0.57707 \\
\hline
\end{tabular}

B. Determination of the Normal Force and Bending Moment Capacities of Columns

The calculation of the normal force and bending moment capacities of columns for the direction $X$ and $Y$ were achieved according to [4]. In the performance calculation, the ground and first floor connections were checked in this way only the normal force and bending moment capacities of these joints were calculated in Table IV. Because two different column dimension also two different column capacity exist and calculated as $\mathrm{N}_{\mathrm{r} 1}=545.70 \mathrm{kN}$ and $\mathrm{N}_{\mathrm{r} 2}=577.20 \mathrm{kN}$.

TABLE IV: MOMENT CAPACITIES OF THE COLUMNS AT FIRST FLOOR

\begin{tabular}{|c|c|c|c|c|c|c|c|c|c|}
\hline $\begin{array}{c}\text { Column } \\
\text { No }\end{array}$ & End & $\begin{array}{c}N_{k} \\
(\mathrm{kN})\end{array}$ & $\begin{array}{c}N_{D} \\
(\mathrm{kN})\end{array}$ & $\begin{array}{c}N_{A} \\
(\mathrm{kN})\end{array}$ & $\begin{array}{c}\text { Column } \\
\text { No }\end{array}$ & End & $\begin{array}{c}N_{k} \\
(\mathrm{kN})\end{array}$ & $\begin{array}{c}N_{D} \\
(\mathrm{kN})\end{array}$ & $\begin{array}{c}N_{A} \\
(\mathrm{kN})\end{array}$ \\
\hline \multirow{2}{*}{1} & $\mathrm{i}$ & 577.2 & 281.705 & 295.495 & \multirow{2}{*}{15} & $\mathrm{i}$ & 545.7 & 319.227 & 226.473 \\
\hline & $\mathrm{j}$ & 577.2 & 268.58 & 308.62 & & $\mathrm{j}$ & 545.7 & 310.039 & 235.661 \\
\hline \multirow{2}{*}{2} & $\mathrm{i}$ & 577.2 & 335.995 & 241.205 & \multirow{2}{*}{16} & $\mathrm{i}$ & 545.7 & 278.886 & 266.814 \\
\hline & $\mathrm{j}$ & 577.2 & 322.87 & 254.33 & & $\mathrm{j}$ & 545.7 & 269.699 & 276.001 \\
\hline \multirow{2}{*}{3} & $\mathrm{i}$ & 577.2 & 359.123 & 218.077 & \multirow{2}{*}{17} & i & 545.7 & 388.583 & 157.117 \\
\hline & $\mathrm{j}$ & 577.2 & 345.998 & 231.202 & & $\mathrm{j}$ & 545.7 & 379.396 & 166.304 \\
\hline \multirow{2}{*}{4} & $\mathrm{i}$ & 577.2 & 364.24 & 212.96 & \multirow{2}{*}{18} & $\mathrm{i}$ & 545.7 & 338.96 & 206.74 \\
\hline & $\mathrm{j}$ & 577.2 & 351.115 & 226.085 & & $\mathrm{j}$ & 545.7 & 329.773 & 215.927 \\
\hline \multirow{2}{*}{5} & $\mathrm{i}$ & 577.2 & 359.123 & 218.077 & \multirow{2}{*}{19} & $\mathrm{i}$ & 545.7 & 418.031 & 127.669 \\
\hline & $\mathrm{j}$ & 577.2 & 345.998 & 231.202 & & $\mathrm{j}$ & 545.7 & 408.843 & 136.857 \\
\hline 6 & $\mathrm{i}$ & 577.2 & 335.995 & 241.205 & 20 & $\mathrm{i}$ & 545.7 & 363.906 & 181.794 \\
\hline
\end{tabular}

\begin{tabular}{|c|c|c|c|c|c|c|c|c|c|}
\hline & $\mathrm{j}$ & 577.2 & 322.87 & 254.33 & & $\mathrm{j}$ & 545.7 & 354.719 & 190.981 \\
\hline \multirow{2}{*}{7} & $\mathrm{i}$ & 577.2 & 281.705 & 295.495 & \multirow{2}{*}{21} & . & 545.7 & 424.216 & 121.484 \\
\hline & $\mathrm{j}$ & 577.2 & 268.58 & 308.62 & & $\mathrm{j}$ & 545.7 & 415.029 & 130.671 \\
\hline \multirow{2}{*}{8} & $\mathrm{i}$ & 577.2 & 250.214 & 326.986 & \multirow{2}{*}{22} & $i$ & 545.7 & 369.086 & 176.614 \\
\hline & $\mathrm{j}$ & 577.2 & 237.089 & 340.111 & & $\mathrm{j}$ & 545.7 & 359.899 & 185.801 \\
\hline \multirow{2}{*}{9} & $\mathrm{i}$ & 577.2 & 298.092 & 279.108 & \multirow{2}{*}{23} & & 545.7 & 418.031 & 127.669 \\
\hline & $\mathrm{j}$ & 577.2 & 284.967 & 292.233 & & $\mathrm{~J}$ & 545.7 & 408.843 & 136.857 \\
\hline \multirow{2}{*}{10} & $\mathrm{i}$ & 577.2 & 319.003 & 258.197 & \multirow{2}{*}{24} & & 545.7 & 363.906 & 181.794 \\
\hline & $\mathrm{j}$ & 577.2 & 305.878 & 271.322 & & $\mathrm{j}$ & 545.7 & 354.719 & 190.981 \\
\hline \multirow{2}{*}{11} & $\mathrm{i}$ & 577.2 & 323.799 & 253.401 & \multirow{2}{*}{25} & i & 545.7 & 388.583 & 157.117 \\
\hline & $\mathrm{j}$ & 577.2 & 310.674 & 266.526 & & $\mathrm{~J}$ & 545.7 & 379.396 & 166.304 \\
\hline \multirow{2}{*}{12} & $\mathrm{i}$ & 577.2 & 319.003 & 258.197 & \multirow{2}{*}{26} & & 545.7 & 338.96 & 206.74 \\
\hline & $\mathrm{j}$ & 577.2 & 305.878 & 271.322 & & J & 545.7 & 329.773 & 215.927 \\
\hline \multirow{2}{*}{13} & $\mathrm{i}$ & 577.2 & 298.092 & 279.108 & \multirow{2}{*}{27} & 1 & 545.7 & 319.227 & 226.473 \\
\hline & $\mathrm{j}$ & 577.2 & 284.967 & 292.233 & & J & 545.7 & 310.039 & 235.661 \\
\hline \multirow{2}{*}{14} & $\mathrm{i}$ & 577.2 & 250.214 & 326.986 & \multirow{2}{*}{28} & 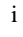 & 545.7 & 278.886 & 266.814 \\
\hline & $\mathrm{j}$ & 577.2 & 237.089 & 340.111 & & $\mathrm{j}$ & 545.7 & 269.699 & 276.001 \\
\hline
\end{tabular}

Shear force control were performed in accordance with the bending capacity at critical sections of structural system components. Columns, beams and walls are to be assumed ductile, $V_{e}$ shear force have to be calculated in accordance with the bending capacity in the critical sections with respect to bending capacity of the critical sections which calculated shear capacity $V_{r}$ will not exceed. Shear force controls compatible with bending capacity of columns were achieved for $X$ and $Y$ directions. Similarly shear force controls compatible with bending capacity of beams were achieved for both directions. All calculated $V_{r}$ values are more than all $V_{e}$ than all of the beams in the structure are ductile.

\section{Performance Evaluation for Structural Elements}

As a result of analysis made on model created in Sap2000, $M_{E}$ values were obtained and "effect / capacity ratios" $(r)$ of beams were calculated using redundant moment capacity $M_{A}$. Performance evaluation of beams have been performed using $M_{E}$ and $M_{A}$ defined in Eq. 5 and effect / capacity ratios ( $r$ ) which defines the boundary of the damage for concrete beams were calculated. Similarly, effect / capacity ratio of infilled walls are the shearing force strength of shearing force calculated under the effect of earthquake.

Using the calculated normal force $\left(N_{K}\right)$ and moment $\left(M_{K}\right)$ capacities of the columns, effect / capacity ratios (r) of the columns were calculated and the boundaries of the damage for columns were determined [4].

$$
\begin{aligned}
& r=N_{E} /\left(N_{K}-N_{D}\right) \\
& r=M_{E} /\left(M_{K}-M_{D}\right)
\end{aligned}
$$

The most damaged section is taken into account while the boundary of the damage of any column is determined. MN, GV and GC intermediate values were found by interpolation.

As a result of the performance analysis with linear elastic calculation methods of the existing infilled building, the percentages of damages of beams and columns calculated under the effect of earthquakes in both directions are given in Table V. Especially at the ground floor of the building, it is a big problem that some of the structural elements of the system are in the Collapsing Region. 
TABLE V: DAmage Percentages and Sectional Damaged States For EXISTING INFILLED BUILDING

\begin{tabular}{c|ccc|ccc}
\hline \multirow{2}{*}{$\begin{array}{c}\text { Ground } \\
\text { Floor }\end{array}$} & MHB \%BHB \% & $\begin{array}{c}\text { IHB } \\
\%\end{array}$ & GB $\%$ & MHB \% BHB \% IHB \% GB \% \\
\hline Columns & 71.4 & 25 & 3.6 & 39 & 61 & \\
Beams & & 40 & 60 & & 33 & 67 \\
\hline
\end{tabular}

\section{CONCLUSIONS}

The following concluding remarks were obtained as a result of Performance based design evaluation performed on a 55 years old building:

The existing old industrial R.C. building was modelled 3-D and analyzed by SAP2000 to make earthquake analysis of the structure. All of the reinforcements are rusty plain bars affected by corrosion while yield strength of steel reinforcement bars is almost $160 \mathrm{MPa}$. Meanwhile, average compressive strength of the concrete samples taken from the building is almost $8 \sim 10 \mathrm{MPa}$. In fact, earthquake safety of a building depends on using material quality beside structural factors.

Performance evaluation of the building was achieved and the effect of infill walls on the seismic performance of the structure has been investigated. According to the results from the performance evaluation of entire building; $71.4 \%$ of the columns are in Marked Damage Region (BHB) for $\mathrm{X}$ direction and $39.0 \%$ for $\mathrm{Y}$ direction while $3.6 \%$ of the columns are in Collapsing Region (IHB) for $\mathrm{X}$ direction and $0 \%$ for $\mathrm{Y}$ direction. On the other hand, the same model without any infill wall (Brick, white stone or concrete) was analyzed then all of the columns and beams would have been in Advanced Damage Region or Collapsing Region for both $\mathrm{X}$ and $\mathrm{Y}$ directions. As a result, the contribution of the infill walls to the strength and stiffness of entire structure can be easily demonstrated. These results from performance based design procedure indicate that infill walls in the building are the main reason why this insufficient building in terms of earthquake resistance has been survived since 55 years.

\section{REFERENCES}

[1] J. L. Gross and L.T. Phan, "Implications for earthquake risk reduction in the United States From the Kocaeli, Turkey, Earthquake of August 17, 1999," ASCE World Structural Engineering Conference (USGS Circular 1193), vol. 1193, 2000.

[2] FEMA 154, ATC-21, Rapid Visual Screening of Buildings for Potential Seismic Hazards: A Handbook, Federal Emergency Management Agency; FEMA-Washington, 1988.

[3] ASCE 31-03, Seismic Evaluation of Existing Buildings, American Society of Civil Engineers, USA, 2003.

[4] Turkish Earthquake Code, The Specifications for Structures to be Built in Earthquake Areas, T.C. Ministry of Environment and City Planning, Turkey, 2007.
[5] U. Albayrak, E. Ünlüoğlu, and M. Doğan, "An overview of the modelling of infill walls in framed structures," International Journal of Structural and Civil Engineering Research, vol. 6, no. 1, pp. 24-29, February 2017. doi: 10.18178/ijscer.6.1.24-29

[6] P. G. Asteris and D. M. Cotsovos, "Numerical investigation of the effect of infill walls on the structural response of RC frames," The Open Construction and Building Technology Journal, vol. 6, pp.164-181, 2012

[7] M. Bruneau, "State of the art report on seismic performance of unreinforced masonry buildings", Journal of Structural Engineering, Vol. 120, issue 1, 230-251, 1994.

[8] B. Kehoe, "Standardizing seismic evaluation of existing buildings" presented at the 13th World Conference on Earthquake Engineering, 2004.

[9] L. Minhee, Y. Changhwan, K. Taejin, and K. Jong-Ho, "Performance-based seismic design of high-rise apartment buildings in Korea considering collapse prevention level," Journal of the Earthquake Engineering Society of Korea, vol. 20, Issue 3, pp.181-190, 2016.

[10] S. Shoeibi, M. A. Kafi, and M. Gholhaki, "New performance-based seismic design method for structures with structural fuse system," Engineering Structures, vol. 132, pp. 745-760, 2017.

[11] S. A. El-Betar, "Seismic vulnerability evaluation of existing R.C. buildings," HBRC Journal, 2016, ISSN 1687-4048.

[12] S. A. El-Betar, "Seismic performance of existing R.C. framed buildings," HBRC Journal, 2015, ISSN 1687-4048.

[13] M. Khan, Earthquake-Resistant Structures Design, Build and Retrofit, ISBN 978-0323281867, pp. 448, 2013

[14] Computers and Structures, Sap2000 User Manual v15, Berkeley, CA, USA, 2011

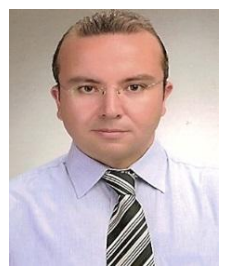

Uğur Albayrak received his B.Sc. (civil engineering), M.Sc (structural engineering) and $\mathrm{PhD}$. (structural engineering) from Eskisehir Osmangazi University (ESOGU) Dept. of Civil Engineering, Turkey. He is presently working as an assistant professor at the same department. His main research interests include design of steel structures, R.C. structures, earthquake resistant design and computer applications in Civil Eng., and having more than 10 publications in national and international journals.

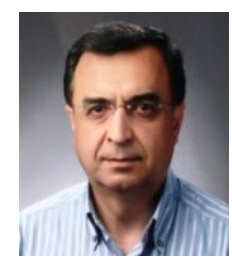

Eşref Ünlüoğlu received his B.Sc. from Eskisehir State Engineering and Architectural Academy (civil engineering); M.Sc. from Yildiz Technical University (structural engineering) and $\mathrm{PhD}$. from Anadolu University (structural engineering), Turkey. He has been working as Professor at Civil Engineering Department of ESOGU and he is also head of civil engineering department now. His main research interests are steel structures, structural analysis and having more than 30 publications in national and international journals.

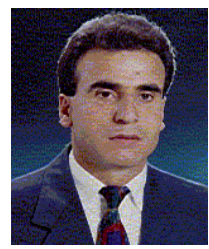

Mizam Doğan received his B.Sc.(civil engineering) and M.Sc (structural engineering) from Anadolu University and $\mathrm{PhD}$. from Eskisehir Osmangazi University (structural engineering), Turkey. He has been working as associate professor at Civil Engineering Department of ESOGU and he is also vice chairman of civil engineering department now.

His main research interests include earthquake resistant design, R.C. structures, structural analysis, prefabricated buildings, maintenance-rehabilitation of structures and having more than 30 publications in national and international journals. 